\title{
Kontribusi Penerapan Metode Qiroati Dalam Pembelajaran Membaca Al- Qur'an Secara Tartil
}

\author{
Sholeh Hasan ${ }^{1 *}$, Tri Wahyuni ${ }^{2}$ \\ 1,2 STKIP Nurul Huda Sukaraja OKU Timur \\ "E-mail: sholehhasan@stkipnurulhuda.ac.id
}

\begin{abstract}
Abstrak
Metode qiroati merupakan metode pengajaran dan pembelajaran Al-Qur'an secara tartil, bertajwid, dibaca secara langsung tanpa di eja. Metode qiroati merupakan salah satu metode baca Al-Qur'an yang yang diterapkan di TPA Mamba'ul Ulum yang kini dapat memberikan kontribusi dalam rangka meningkatkan pembelajaran AI-Qur'an di TPA Mamba'ul Ulum.

Dengan menggunakan pendekatan deskriptif kualitatif, penelitian ini dilakukan untuk mendeskripsikan dan menganalisa tentang kontribusi penerapan metode qiroati dalam pembelajaran membaca Al-Qur'an secara tartil. Sebagai kegiatan akhir analisis data penelitian dapatlah disimpulkan: kontribusi penerapan metode qiroati dalam pembelajaran membaca Al-Qur'an secara tartil di TPA Mamba'ul Ulum Sukaraja sangat bermanfaat. Hal ini dapat di lihat dari angket yang disebarkan kepada seluruh santri jilid 4 TPA Mamba'ul Ulum. Berdasarkan skor jawaban kontribusi penerapan metode qiroati diketahui bahwa santri yang menjawab sangat bermanfaat sebanyak 26 santri (86.67\%), yang menjawab kontribusi penerapan metode qioati cukup bermanfaat sebanyak 4 santri (13.33\%), yang menjawab kontribusi penerapan metode qiroati kurang bermanfaat sebanyak 0 santri $(0 \%)$, yang menjawab kontribusi penerapan metode qiroati di ketahui bahwa santri yang menjawab tidak bermanfaat sebanyak 0 santri $(0 \%)$. Kontribusi penerapan metode qiroati dalam pembelajaran membaca $\mathrm{Al}$ Qur'an secara tartil di TPA Mamba'ul Ulum Sukaraja adalah sangat bermanfaat dalam meningkatkan prestasi belajar santri TPA Mamba'ul Ulum Sukaraja.
\end{abstract}

Kata kunci: Metode Qiroati, Pembelajaran Membaca Al-Qur'an, Tartil.

\section{PENDAHULUAN}

Pendidikan adalah suatu yang esensial bagi manusia. Melalui pendidikan manusia dapat belajar menghadapi segala problematika ysng ada di alam semesta ini demi mempertahankan kehidupannya. (Ali dan Ali, 2003: vii). Sesuai dengan jiwa dan nilai ajaran islam mengenai pengetahuan dan kecerdasan manusia, maka setiap usaha ilmu pengetahuan haruslah dikembangkan dengan tujuan untuk mencerdaskan manusia sehingga mempunyai peluang lebih besar untuk memahami dan menyadari dirinya di tengah-tengah keserbaadaan alam dan jagat raya.

Di antara tugas yang memerlukan keseriusan dan kepedulian yang ekstra dari setiap pendidik adalah tugas mencari metode terbaik untuk mengajarkan Al-Qur'an kepada anak-anak, sebab mengajarkan Al-Qur'an (kepada mereka) merupakan salah satu pokok dalam ajaran Islam. Tujuannya adalah agar mereka tumbuh sesuai dengan fitrahnya dan hati mereka pun bisa dikuasai cahaya hikmah, sebelum dikuasai hawa nafsu dengan berbagai nodanya yang terbentuk melalui kemaksiatan dan kesesatan. Supaya dalam kegiatan belajar AI-Qur'an dapat berjalan dengan lancar, maka banyak sekali solusi yang digunakan yaitu dengan metode cara cepat baca Qur'an di antaranya adalah dengan menggunakan Metode Iqro', Tilawati, Qiroati, Baghdadiyah, Nahdliyah, Al Barqy dan lain-lain. Namun yang akan penulis bahas di sini yang digunakan untuk mengatasi tersebut adalah metode qiroati

Metode qiroati merupakan metode yang lebih menekankan pada pendekatan ketrampilan proses membaca secara cepat dan tepat, baik pada makhorijul khuruf-nya maupun bacaan tajwidnya, sehingga akan diperoleh hasil pengajaran yang efektif tahan lama dan dapat dikembangkan sesuai 
dengan kondisi kemampuan anak didik. Untuk mengajar metode qiroati ini tidak sembarang orang yang mengajar karena sebelum mengajar para ustadz-ustadzahnya di tashih terlebih dahulu sehingga siswa dapat belajar dengan baik dan benar. Kualitas ustadzahnya dalam membaca AlQur'an selalu terpantau karena ada tadarrus bersama. Selain itu dalam metode ini juga terdapat petunjuk membacanya pada setiap jilidnya sehingga para siswa yang aktif dalam membaca sedangkan guru hanya membimbing dan membenarkan bacaan yang salah. Jadi, dalam penerapan metode ini siswa yang lebih banyak aktif sehingga akan selalu ingat dengan apa yang dipelajarinya karena para ustadz-ustadzahnya tidak memindahkan halaman sebelum siswa itu benar-benar bisa membaca dengan makhroj yang baik dan benar.

\section{METODE/EKSPERIMEN}

Jenis penelitian yang digunakan adalah Penelitian kualitatif, Untuk mendeskripsikan kontribusi penerapan metode qiroati serta faktor pendukung dan penghambat dalam pembelajaran membaca Al-Qur'an secara tartil di Taman Pendidikan Al-Qur'an Mamba'ul Ulum Sukaraja. Meleong (2007:6) menjelaskan pengertian penelitian kualitatif dapat diartikan sebagai metode penelitian yang bermaksud untuk memahami fenomena tentang apa yang dialami oleh subjek penelitian misalnya prilaku, presepsi, motivasi, tindakan dan lain-lain, secara holistik dan dengan cara deskripsi dalam bentuk kata-kata dan bahasa, pada suatu konteks khusus yang ilamiah dan dengan memanfaatkan berbagai metode alamiah. Dari penelitian ini juga menggunakan populasi dan sampel. Sampel dalam Penelitian ini yaitu santri jilid IV. Dalam Penelitian ini, peneliti menggunakan pengumpulan data berupa observasi, interview, dokumentasi, serta angket.

\section{HASIL DAN PEMBAHASAN}

\section{Hasil}

Almarhum KH. Dachlan Salim Zarkasyi dalam perjalanan menyusun metode baca tulis AlQur'an sering melakukan studi banding ke berbagai pesantren dan madrasah Al-Qur'an hingga beliau sampai ke Pesantren Sedayu Gresik Jawa Timur (tepatnya pada bulan Mei 1986) yang pada saat itu dipimpin oleh Almukarram K.H. Muhammad. Almarhum K.H. Dachlan Salim Zarkasyi tertarik untuk melakukan studi banding sekaligus bersilaturahim ke Pesantren Sedayu Gresik, karena TK Al-Qur'an balitanya (4-6 tahun), yang dirintis oleh K.H. Muhammad sejak tahun 1965 dengan jumlah muridnya 1300 siswa yang datang dari berbagai kepulauan yang ada di Indonesia. Maka dapat disimpulkan TK Al-Qur'an Sedayu adalah TK Al-Qur'an pertama di Indonesia bahkan di dunia.

Sebulan setelah KH. Dachlan Salim Zarkasyi silaturahmi ke Pesantren Sedayu Gresik tepatnya pada tanggal 1 Juli 1986, beliau mencoba membuka TK Al-Qur'an yang sekaligus mempraktikkan dan mengujikan metode yang disusunnya sendiri dengan target rancana 4 tahun seluruh muridnya akan khatam Al-Qur'an. Berkat Inayah Allah SWT di luar dugaan dalam perjalanan 7 bulan ada beberapa siswa yang telah mampu membaca beberapa ayat Al-Qur'an, serta dalam jangka waktu 2 tahun telah mengkhatamkan Al-Qur'an dan mampu membaca dengan baik dan benar (bertajwid). TK Al-Qur'an yang dipimpinnya makin dikenal keberbagai pelosok karena keberhasilan mendidik siswasiswinya. Dari keberhasilan inilah banyak yang melakukan studi banding dan meminta petunjuk cara mengajarkan metode yang diciptakannya. K.H. Dachlan Salim Zarkasyi secara terus-menerus melakukan evaluasi dan meminta penilaian dah para Kyai Al-Qur'an atas motode yang diciptakannya. Atas usul dari Ustadz A. Djoned dan Ustadz Syukri Taufiq, metode ini diberi istilah dengan nama "QIRAATI" dibaca "QIROATI" yang artinya BACAANKU (pada saat itu ada 10 jilid). (Dachlan Salim Zarkasyi, 1996:10)

Memperhatikan perjalanan sejarah penyusunan metode qiroati, tampaknya K.H. Dachlan Salim Zarkasyi sangat didukung oleh para Kyai umul Qur'an, walaupun menurut penuturannya beliau ini bukanlah santri namun kehidupannya selalu dekat dengan para Kyai sehingga tampak tawadu', mukhtish dan berwibawa. Atas restu para Kyai metode qiroati selanjutnya menyebar luas dan 
digunakan sebagai materi dasar dalam pengajaran baca tulis Al-Qur'an di masjid, madrasah, TKA, TPA, TPQ, Pesantren dan Sekolah Umum. Qiroati diminati oleh mayoritas para pendidik Al-Qur'an dikarenakan memiliki beberapa perbedaan dengan metode lain diantaranya :

1. Berkesinambungan antara halaman ke halaman berikutnya.

2. Berkesinambungan antara jilid satu dan seterusnya.

3. Disesuaikan dengan usia para pelajar Al-Qur'an.

4. Kata dan kalimatnya tidak keluar kaidah ayat-ayat Al-Qur'an tidak kedaerahan.

5. Setiap pokok bahasan sudah diterapkan ilmu tajwid.

6. Dilengkapi petunjuk mengajar setiap pokok bahasan.

7. Dilengkapi buku gharib, Musykilat dan tajwid praktis.

8. Sangat mudah untuk diucapkan.

Dari tahun ketahun perkembangan Qiroati makin meluas keseluruh pelosok negeri bahkan di beberapa negara asing tercatat sampai tahun 2000 telah masuk ke negara Australia, Malaysia, Brunei Darusalam, Singapura. Dari perkembangan tersebut Almarhum K.H. Dachlan Salim Zarkasyi tidak terlalu gembira bahkan merasa khawatir karyanya ini disalah gunakan yang berbau bisnis belaka, untuk itu pada tahun 1990 beliau mengundang seluruh kepala TKA/TPA dan lembaga yang mempergunakan qiroati pada suatu acara Silatnas Nasional untuk mentashih ulang para kepala TKA/TPA dan pengelola qiroati sekaligus menunjuk koordinator tingkat propinsi dan kota besar yang ada di Indonesia.

\section{a. Tujuan Metode Qiroati}

Adapun tujuan dari metode qiroati di antaranya yaitu:

1) Menjaga dan memelihara kehormatan dan kesucian Al-Qur'an dari segi bacaan tartil sesuai dengan kaidah tajwid.

2) Menyebarluaskankan ilmu bacaan Al-Qur'an yang benar dengan cara yang benar pula.

3) Mengingatkan para guru Al-Qur'an agar berhati-hati dalam mengajarkan Al-Qur'an.

4) Meningkatkan kualitas pendidikan atau pengajaran ilmu baca Al-Qur'an di tengah-tengah masyarakat.

\section{b. Target Penggunaan Metode Qiroati}

Adapun target penguanaan metode qiroati di antaranya yaitu :

1) Untuk anak-anak pra sekolah TK (usia 4-6 tahun) .

2) Untuk remaja.

3) Orang dewasa.

\section{c. Kelebihan Dan Kekurangan Metode Qiroati}

Kelebihan metode qiroati antara lain yaitu:

1) Praktis, mudah dipahami dan dilaksanakan oleh peserta didik.

2) Dalam metode ini terdapat prinsip untuk guru dan murid.

3) Peserta didik aktif dalam belajar membaca, guru hanya menjelaskan pokok pembelajaran dan memberi contoh bacaan.

4) Siswa walaupun belum mengenal tajwid tetapi sudah bisa membaca Al-Qur'an langsung fasih dan tartil dengan ilmu tajwidnya. Karena belajar ilmu tajwid itu hukumnya fardlu kifayah sedangkan membaca Al-Qur'an dengan tajwidnya itu fardlu'ain.

5) Peserta didik menguasai ilmu tajwid dengan praktis dan mudah.

6) Pada metode ini setelah khatam meneruskan lagi bacaan gharib.

7) Jika santri sudah lulus 6 Jilid beserta ghoribnya, maka ditest bacaannya kemudian setelah itu santri mendapatkan syahadah jika lulus tes.

Sedangkan kekurangan metode qiroati yaitu:

1) Anak tidak bisa membaca dengan mengeja.

2) Anak kurang menguasai huruf hijaiyah secara urut dan lengkap.

3) Bagi anak yang tidak aktif akan semakin tertinggal.

4) Bagi yang tidak lancar lulusnya juga akan lama karena metode ini lulusnya tidak ditentukan 
oleh bulan/tahun.

\section{d. Prinsip - Prinsip Dasar Qiroati}

Prinsip-prinsip dasar qiroati terbagi menjadi 2 di antaranya yaitu :

1. Prinsip-prinsip yang di pegang oleh guru/ustadz yaitu:

a) DAKTUN (Tidak Boleh Menuntun)

Dalam hal ini ustadz - ustadzah hanya menerangkan pokok pelajaran, memberikan contoh yang benar, menyuruh santri membaca sesuai dengan contoh menegur yang salah, menunjukkan kesalahan bacaan dan membetulkan.

b) TIWAGAS (Teliti, Waspada dan Tegas)

Maksud dari TIWAGAS tersebut adalah Teliti artinya dalam memberikan contoh atau menyimak ketika santri membaca jangan sampai ada yang salah walaupun sepele. Waspada artinya dalam memberikan contoh atau menyimak bacaan santri benar - benar diperhatikan, ada rasa sambung dari hati ke hati. Tegas maksudnya dalam memberikan penilaian ketika menaikkan halaman atau jilid tidak boleh banyak toleransi, ragu-ragu ataupun segan. Penilaian yang diberikan harus benar-benar obyektif.

2. Prinsip-prinsip yang harus dipegang santri/anak didik:

a) CBSA+M : Cara Belajar Santri Aktif dan Mandiri.

Santri dituntut keaktifan, konsentrasi dan memiliki tanggung jawab terhadap dirinya tentang bacaan Al Qur'annya, sedangkan ustadz - ustadzah sebagai pembimbing, motivator dan evaluator saja.

b) LCTB : Lancar Cepat Tepat dan Benar.

Maksud dari pengertian LCTB yaitu Lancar artinya bacaannya tidak mengulang ulang. Cepat berarti bacaanya tidak ada yang putus - putus atau mengeja. Tepat bermakna dapat membunyikan sesuai dengan bacaan dan dapat membedakan antara bacaan yang satu dengan lainnya. Benar maksudnya hukum - hukum bacaan tidak ada yang salah.

Dalam mengajarkan qiroati ada jilid I sampai jilid VI yaitu:

a) Jilid I

Jilid I adalah kunci keberhasilan dalam belajar membaca Al-Qur'an. Apabila jilid I lancar pada jilid selanjutnya akan lancar pula, guru harus memperhatikan kecepatan santri.

b) Jilid II

Jilid II lanjtan jilid I yang disini telah terpenuhi target jilid I.

c) Jilid III

Jilid III adalah setiap pokok bahasan lebih ditekankan pada bacaan panjang (huruf mad).

d) Jilid IV

Jilid IV merupakan kunci keberhasilan dalam bacaan tartil dan tajwid.

e) Jilid V

Jilid V ini lanjutan dari jilid IV. Disini diharapkan sudah harus mampu membaca dengan baik dan benar.

f) Jilid VI

Jilid VI adalah jilid yang terakhir yang kemudian dilanjutkan dengan pelajaran juz.

\section{e. Strategi Mengajar dalam Qiroati}

Dalam mengajar Al-Qur'an dikenal beberapa macam stategi Yaitu:

1. Strategi mengajar umum (global)

a) Individu atau privat yaitu santri bergiliran membaca satu persatu.

b) Klasikal Individu yaitu sebagian waktu digunakan guru/ustadz untuk menerangkan pokok pelajaran secara klasikal.

c) Klasikal baca simak yaitu strategi ini digunakan untuk mengajarkan membaca dan menyimak bacaan Al-quran orang lain. 
2. Strategi mengajar khusus (detil)

Agar kegiatan belajar mengajar Al-Qur'an dapat berjalan dengan baik sehingga tercapai keberhasilan yang maksimal maka perlu diperhatikan syarat-syarat sebagai berikut :

a) Guru harus menekan kelas, dengan memberi pandangan menyeluruh terhadap semua santri sampai semuanya tenang, kemudian mengucapkan salam dan membaca do'a iftitah.

b) Pelaksanaan pelajaran selama satu jam ditambah 15 menit untuk variasi (do'a - do'a harian, bacaan sholat, do'a ikhtitam atau hafalan-hafalan lainnya).

c) Usahakan setiap anak mendapat kesempatan membaca satu persatu.

d) Wawasan dan kecakapan anak harus senantiasa dikembangkan dengan sarana dan prasarana yang ada.

e) Perhatian guru hendaknya menyeluruh, baik pada anak yang maju membaca maupun yang lainnya.

f) Penghayatan terhadap jiwa dan karakter anak sangat penting agar anak tertarik dan bersemangat untuk memperhatikan pelajaran. Jika ada yang diam terus dan tidak mau membaca maka guru harus tetap membujuknya dengan sedikit pujian.

g) Motivasi berupa himbauan dan pujian sangat penting bagi anak, terutama anak Pra TK. Anak jangan selalu dimarahi, diancam atau ditakut-takuti. Tapi kadang kala perlu dipuji dengan kata-kata manis, didekati serta ucapan dan pendapatnya ditanggapi dengan baik.

h) Guru senantiasa menanti kritik yang sifatnya membangun demi meningkatkan mutu TKQ. Jangan cepat merasa puas.

i) Jaga mutu pendidikan dengan melatih anak semaksimal mungkin.

j) Idealnya untuk masing-masing kelas/jilid terdiri dari :

$>$ Pra Taman Kanak-kanak : 10 anak

$>$ Jilid I: 15 anak

$>$ Jilid II - Al-Qur'an : 20 anak Masing-masing dengan seorang guru.

k) Agar lebih mudah dalam mengajar, sebaiknya disediakan alat-alat peraga dan administrasi belajar mengajar di dalam kelas, antara lain : Buku data siswa, buku absensi siswa, Kartu/Catatan prestasi siswa (dipegang siswa), dan lain-lain.

\section{f. Langkah-Langkah Penerapan Metode Qiroati}

Adapun langkah-langkah dalam penerapan metode qiroati meliputi:

1. Praktis Artinya : langsung (tidak dieja). Contoh : أَ baca, A-BA (bukan Alif fatha $\mathrm{A}, \mathrm{Ba}$ fatha BA), dan dibaca pendek. Jangan di baca panjang Aa Baa, atau Aa Ba atau, A Baa

2. Sederhana artinya : kalimat yang dipakai menerangkan diusahakan sederhana asal dapat difahami, cukup memperhatikan bentuk hurufnya saja, jangan menggunakan keterangan yang teoritis/devinitif. Cukup katakan : Perhatikan ini ! ب Bunyinya = BA Cukup katakan : Perhatikan titiknya ! ini BA, ini TA, dan ini TSA.

3. Sedikit demi sedikit, tidak menambah sebelum bisa lancar.

4. Merangsang murid untuk saling berpacu. Setelah kita semua tau mengajarkan qiroati tidak boleh menambah pelajaran baru sebelum bisa membaca dengan benar dan cepat, maka cara yang tepat adalah menciptakan suasana kompetisi dan persaingan sehat dalam kelas, cara ini insya Allah akan memacu semangat dan mencerdaskan anak.

5. Tidak menuntun untuk membaca. Seorang guru cukup menerangkan dan membaca berulang-ulang pokok bahasan pada setiap babnya sampai anak mampu membaca sendiri tanpa dituntun latihan di bawahnya. Metode ini bertujuan agar anak faham terhadap pelajrannya, tidak sekedar hafal.

6. Waspada terhadap bacaan yang salah.

7. Driil (bisa karena biasa). Metode drill banyak tersirat pada buku qiroati, adapun yang secara 
khusus menggunakan metode ini adalah pada pelajaran : Ghorib IImu Tajwid, dan Hafalanhafalan biarpun tanpa ada kewajiban menghafal di rumah, insyaallah dengan metode drill ini semua pelajaran hafalan akan hafal dengan sendirinya.

\section{g. Pembelajaran Membaca AI-Qur'an secara Tartil}

Sebelum membahas tentang pembelajaran membaca Al-Qur'an, terlebih dahulu diuraikan tentang pengertian dari istilah tersebut.

1. Pengertian Membaca

Membaca berasal dari kata "baca" yaitu melihat serta memahami isi dari apa yang tertulis dengan melisankan atau hanya dalam hati.

Dalam literatur pendidikan islam istilah baca mengandung dua penekanan yaitu: tilawah dan qiraah. Istilah tilawah mengandung makna mengikuti (membaca) apa adanya baik secara fisik maupun mengikuti jejak dan kebijaksanaan, atau membaca apa adanya sesuai dengan aturan bacaan yang benar dan baik. Sedangkan qiraati mengandung makna menyampaikan, menelaah, membaca, meneliti, mengkaji, mendalami, mengetahui ciri-ciri atau merenungkan, terhadap bacaan-bacaan yang tidak harus berupa teks tertulis. Makna baca tidak sekedar tilawah tapi juga qiraah.

2. Pengertian Al-Qur'an

Kata Qur'an yang berarti "bacaan" secara gramatikal diturunkan dari kata bahasa arab qora'a yang berarti "membaca". Namun, Al-Qur'an bukan bacaan biasa. Al-Qur'an adalah kalamullah, firman Allah, atau perkataan Allah, yang tentu saja tidak sam dengan perkataan manusia. Membaca Al-Qur'an merupakan salah satu bentuk ibadah yang mendapat pahala, apalagi bila dibaca dengan tartil, yaitu dengan merdu, tertib, dan menurut bacaan tajwid.

Al-Qur'an menurut pendapat yang paling kuat seprti dikemukakan Subhi Al Shalih (2002: 24) berarti bacaan berasal dari qaraa. Kata Al-Qur'an itu berbentuk masdar dengan arti isim maf'ul yaitu maqru (dibaca). Sesuai dengan Allah berfirman dalam Qur'an Surah Al-Qiyamah ayat $17-18$ yang berbunyi :

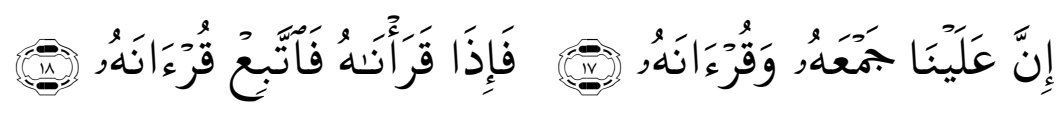

Artinya: "Sesungguhnya atas tanggungan kamilah mengumpulkannya (di dadamu) dan (membuatmu pandai) membacanya". Apabila Kami telah selesai membacakannya Maka ikutilah bacaannya itu. (QS. Al-Qiyamah: 17-18). Kemenag RI (2014: 577).

Sedangkan menurut istilah Al-Qur'an adalah mukjizat yang diturunkan oleh Allah SWT kepada Nabi Muhammad S.A.W secara mutawatir dan berangsur-angsur melalui malaikat Jibril sebagai sumber hukum dan pedoman bagi pemeluk ajaran agama Islam yang dimulai dengan surah Al-Fatihah dan diakhiri dengan surah An-Nas dan yang membacanya bernilai ibadah.

3. Pengertian Tartil

Tartil menurut bahasa berarti jelas, racak dan teratur, sedang menurut istilah ahli qiroat ialah membaca Al-Qur'an dengan pelan-pelan dan tenang, beserta dengan memikirkan artiarti Al-Qur'an yang sedang dibaca, semua hukum tajwid dan waqof terjaga dengan baik dan benar terpelihara dengan sempurna.

Hal ini berdasarkan kepada Firman Allah SWT. Allah SWT menyandarkan kata 'Tartil' kepada dzat-nya sendiri sebagaimana didalam firman-Nya dalam Qur'an Surah Al-Furqon ayat 32 yang berbunyi :

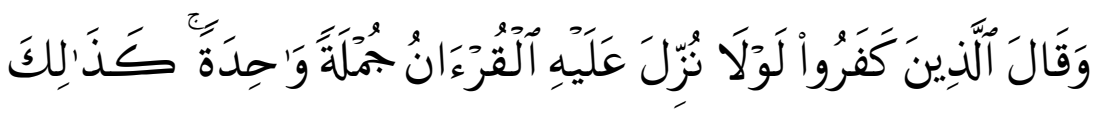




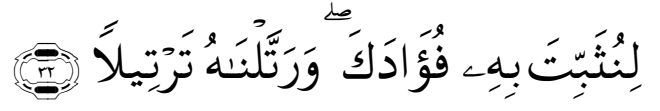

Artinya: "Berkatalah orang-orang yang kafir: "Mengapa Al Quran itu tidak diturunkan kepadanya sekali turun saja?"; demikianlah supaya Kami perkuat hatimu dengannya dan Kami membacanya secara tartil (teratur dan benar). (QS. Al-Furqon: 32). Kemenag RI (2014: 362).

Maksudnya: Al Qur'an itu tidak diturunkan sekaligus, tetapi diturunkan secara berangsurangsur agar dengan cara demikian hati Nabi Muhammad S.A.W menjadi kuat dan tetap.

Menurut qoul sahabat Ali Karomallahu wajhah dalam Matan Jazariyah memberikan definisi tartil sebagai bacaan yang sesuai dengan kaidah tajwid dan waqofnya. Tartil di dalam membaca Al-Qur an terbagi menjadi tiga macam yaitu:

a) Tahqiq

Tahqiq ialah membaca Al-Qur`an dengan pelan - pelan, tenang, perlahan - lahan dan memikirkan arti - artinya serta semua hukum tajwid terpelihara dengan baik, atau hak (makhroj dan sifat) semua huruf terbaca dengan terang dan jelas, bacaan semacam ini adalah bacaan madzhab dari Imam-imam yang membaca mad far'I dan isyba` ( 3 alif), seperti Imam Khamzah dan Waresy.

b) Hader

Hader ialah membaca Al-Qur’an dengan cepat tapi semua hukum tajwid terpelihara dengan baik, seperti Qoshor, ikhtilas, badal, idghom kabir dll, dapat terpelihara dengan benar dan tepat, maksudnya sesuai dengan riwayat yang mutawatir (kondang), bacaan semacam ini, ialah madzhab dari Imam Ibnu Katsir, Abu Amer dan semua Imam Rowi yang membaca mad munfashil dengan (1 alif).

c) Tadwir

Tadwir ialah membaca Al-Qur`an dengan cara antara tahqiq dan hader, atau antara pelan dan cepat, tapi mujawwid (semua hukum tajwid terjaga dengan baik dan benar). Madzhab ini adalah madzhab Imam-imam yang membaca mad munfashil dengan panjang 2 alif atau $2 \frac{1}{2}$ alif, seperti imam Ibnu Amir, Ali Al Kisa'I, Ashim dan lain-lain (Jazari; tt: 15).

Berdasarkan paparan diatas maka keberhasilan suatu pembelajarana Al-Qur'an secara tartil dapat dilihat dari makhorijul khuruf, sifatul khuruf, idhar, ikhfa', iqlab, mad, qolqolah, saktah, waqof dan lain-lainya sesuai dengan kaidah tajwid. Sehingga dalam ketartilan suatu bacaan harus berdasarkan kepada kaidah tajwid tersebut.

Dari pengertian di atas dapat penulis maksudkan Pembelajaran membaca Al-Qur'an secara tartil yaitu suatu proses belajar Al-Qur'an yang dilaksanakan oleh ustadz dan ustadzah dengan santrinya guna untuk mengantarkan santri agar dapat membaca Al-Qur'an dengan baik dan benar sesuai dengan ketentuan kaidah ilmu tajwid.

\section{Pembahasan}

Berdasarkan hasil Penelitian yang diperoleh peneliti, bahwa penerapan metode qiroati dalam pembelajaran membaca Al-Qur'an secara tartil di TPA Mamba'ul Ulum Sukaraja yaitu guru mempersiapkan alat peraga beserta buku penghubung, media, sedangkan murid menyiapkan alatalat tulis, buku qiroati, dan berdo'a bersama-sama. Dalam penerapan metode qiroati terdapat Strategi yang digunakan dalam pembelajaran membaca Al-Qur'an melalui metode qiroati yaitu strategi klasikal-individual, strategi individual, dan strategi klasikal balik. Dalam penerapan ini juga menambahkan materi tambahan berupa hafalan surat-surat pendek, do'a-do'a harian, ghorib dan musykilat, yang terakhir yaitu evaluasi yang dilakukan oleh ketua lembaga. Dari penerapan metode 
qiroati ini kelas dibagi menjadi tiga yaitu kelas dasar untuk kelas qiroati jilid Pra TK. Kelas pasca untuk santri yang sudah khatam Al-Qur'an, dalam kelas pasca ini diberi sedikit materi tambahan berupa materi yang berhubungna dengan materi pendidikan agama islam (baik materi fiqih, akidah akhlak, dan SKI). Untuk faktor pendukung dan penghambat dalam pembelajaran membaca Al-Qur'an secara tartil di TPA Mamba'ul Ulum Sukaraja, dari faktor pendukung seperti hardware (Sarana dan Prasarana), Software (Dana yang Cukup), Brainware (Guru, Santri, Orang Tua). Sedangakan kontribusi penarapan metode qiroati dalam pembelajaran membaca Al-Qur'an secara tartil di TPA Mamba'ul Ulum Sukaraja ini dapat ditinjau dari skor presentase angket penerapan metode qiroati bermanfaat dalam meningkatkan prestasi belajar santri sebesar $86,67 \%$ sangat bermanfaat, $13,33 \%$ cukup bermanfaat. Jadi dapat dikatakan bahwa penerapan metode qiroati ini sangat bermanfaat dalam meningkatkan prestasi belajar santri.

Analisis metode qiroati bermanfaat dalam meningkatkan prestasi belajar santri dapat dilihat pada tebel berikut ini:

Tabel Persentase

\begin{tabular}{|c|l|c|c|}
\hline No & \multicolumn{1}{|c|}{ Alternatif Jawaban } & Frekuensi & presentase \\
\hline 10. & a. Ya sangat bermanfaat & 26 & $86.67 \%$ \\
& b. Cukup bermanfaat & 4 & $13.33 \%$ \\
& c. Kurang bermanfaat & 0 & $0 \%$ \\
& d. Tidak bermanfaat & 0 & $0 \%$ \\
\hline & Jumlah & 30 & $100 \%$ \\
\hline
\end{tabular}

Tabel diatas menunjukan bahwa $86,67 \%$ metode qiroati sangat bermanfaat dalam meningkatkan prestasi belajar santri, dan $13,33 \%$ metode qiroati cukup bermanfaat dalam meningkatkan prestasi belajar santri. Jadi dapat dikatakan bahwa metode qiroati sangat bermanfaat dalam meningkatkan prestasi belajar santri.

Jadi kontribusi dari penerapan metode qiroati dapat meningkatkan keberhasilan yang tinggi dalam pembelajaran membaca Al-Qur'an secara tartil di TPA Mamba'ul Ulum Sukaraja. Sebagai daya pendukung dan penyemangat santri dalam pembelajaran membaca Al-Qur'an. Sebagai sarana dakwah kepada masyarakat dalam rangka memberantas buta huruf Al-Qur'an, serta sebagai bahan informasi yang bermanfaat guna menuju jalan yang diridhoi Allah SWT. Dapat meningkatkan profesionalisme guru dalam pembelajaran Al-Qur'an serta kreatifitas dan inovatif dalam memilih metode pembelajaran Al-Qur'an. Dapat membangun jiwa anak yang qur'ani yaitu generasi yang mencintai Al-Qur'an dan mempunyai komitmen terhadap Al-Qur'an serta memahami isi kandungan Al-Qur'an sehingga dapat mengamalkannya dalam kehidupan sehari-hari. Santri dapat menghafal surat-surat pendek, do'a-doa'a harian, dan ilmu tajwid, ghorib musyikilat.

Hasil dan pembahasan dipaparkan dengan panjang 60-70\% dari panjang artikel. Hasil merupakan bagian utama artikel ilmiah yang berisi: hasil analisis data, hasil pengujian hipotesis, dapat dilengkapi dengan tabel atau grafik, untuk memperjelas hasil secara verbal.

\section{Simpulan}

\section{PENUTUP}

Berdasarkan analisis hasil Penelitian dan pembahasan hasil Penelitian dapat menyimpukan Kontribusi dari penerapan metode qiroati di TPA Mamba'ul Ulum Sukaraja dalam melancarkan baca tulis Al-Qur'an yaitu dengan cara mengurangi angka kesulitan bagi santri dalam membaca Al-Qur'an, dimana santri diharuskan membaca langsung tanpa di eja. Guru mewajibkan semua santri agar mampu dalam membaca Al-Qur'an sesuai dengan ketentuan yang telah ditetapkan. Dari penerapan metode qiroati dapat meningkatkan profesionalisme dalam pembelajaran Al-Qur'an serta kreatifitas dan inovatif dalam memilih metode pembelajarn Al-Qur'an serta dapat membangun jiwa anak yang qur'ani yaitu generasi yang mencintai Al-Qur'an dan mempunyai komitmen terhadap Al-Qur'an serta memahami isi kandungan Al-Qur'an sehingga dapat mengamalkannya dalam kehidupan sehari-hari. 
Setelah mendapat pembelajaran melalui penggunaan metode qiroati pada santri jilid 4 , penerapan metode qiroati memberikan kontribusi dalam meningkatkan prestasi belajar santri yaitu melalui perhitungan angket dengan presentase sebesar $86,67 \%$ sangat bermanfaat, $13,33 \%$ cukup bermanfaat dengan total $100 \%$. Jadi dapat dikatakan bahwa metode qiroati sangat bermanfaat dalam meningkatkan prestasi belajar santri.

\section{Saran}

Sesuai dengan jiwa dan nilai ajaran islam mengenai pengetahuan dan kecerdasan manusia, maka setiap usaha ilmu pengetahuan haruslah dikembangkan dengan tujuan untuk mencerdaskan manusia sehingga mempunyai peluang lebih besar untuk memahami dan menyadari dirinya ditengahtengah keserbaadaan alam dan jagat raya. Maka metode yang dikembangkan ini akan terus mengalami pembaharuan sesuai perkembangan jaman jika diperlukan. Beberapa pegiat pendidikan diharapkan terus mengembangkan dan berinovasi metode-metode yang bisa diterapkan dan kemanfaatan dapat dinikmati oleh berbagai kalangan pencari ilmu demi tumbuhnya kreatifitas dan potensi anak didik, yang pada akhirnya mengarahkan anak didik untuk mencapai satu tujuan yang sebenarnya.

\section{UCAPAN TERIMAKASIH}

Ucapan terimakasih penulis sampaikan kepada beberapa pihak yang turut serta membantu mensukseskan kegiatan pengabdian ini, antara lain:

1. Sekolah Tinggi Keguruan dan IImu Pendidikan (STKIP) Nurul Huda OKU Timur yang sudah memberikan dukungan penuh terhadap tugas dosen terkait tri darma perguruan tinggi.

2. Lembaga Penelitian dan Pengabdian Masyarakat (LPPM) di bawah naungan STKIP Nurul Huda yang telah memberikan support, bimbingan dan arahan dalam melaksanakan program pengabdian kepada masyarakat melaui surat edaran nomor 006/STKIP-NH/LPPM/II/2018 tahun 2018 tentang penandatanganan kontrak hibah STKIP Nurul Huda tahun 2018 periode \#1.

3. TPA Mamba'ul Ulum Sukaraja yang telah memfasilitasi penulis dalam melakukan kegiatan program penelitian, dan

4. Seluruh pihak terkait baik secara personal maupun kelembagaan yang turut serta memberikan kontribusi.

\section{DAFTAR PUSTAKA}

Abid Hakim, Atang. 2009. Metodologi Study Islam. Bandung: PT. Remaja Rosda Karya.

Ali, Muhammad dan Ali. 2003. Strategi Penelitian Pendidikan. Bandung: Angkasa.

Arikunto, Suharsimi. 2005. Prosedur Penelitian Suatu Pendekatan Praktek. Jakarta: PT Rineka Cipta.

Arifin, H. Muzayyin. 2010. Filsafat Pendidikan Islam (Edisi Revisi. Jakarta: Bumi Aksara.

Chaer, Abdul. 2014. Perkenalan awal dengan Al-Qur'an. Jakarta: Penerbit Rineka Cipta.

Dick W. and Carey, L. 1985. The Systematic Design Of Instruction. Second Edition. Glenview, Illinois: Scott, Foreman and Company.

Hadi, Sutrisno. 2001. Metodologi Research. Yogyakarta: Andi Offset.

Hardini, Isriani dan Dewi Puspitasari. 2012. Strategi Pembelajaran Terpadu. Yogyakarta: Familia.

J. Moleong, Lexi. 2002. Metodologi Penelitian Kualitatif. Bandung: PT Remaja Rosda Karya.

Kemenag RI. 2014. Al-Qur'an Tajwid dan Terjemah. Jakarta: Penerbit Abyan.

Margono. 2008. Metodologi Penelitian Pendidikan. Jakarta: PT Rineka Cipta. 
Murjito, Imam. 2003. Pedoman Metode Praktis Pengajaran IImu Al Qur'an Qiroati. Semarang : Pendidikan Al Qur'an Metode Qiroati.

Nasution, S. 2001. Metode Research. Jakarta: Bumi Aksara

Poerwadarminta, W.J.S. 2003. Kamus Umum Bahasa Indonesia. Jakarta: Balai Pustaka.

Qadir Al-Bakry, Abdul. 1998. Fungsi dan Pentingnya Pengajaran Al-Qur'an, Semarang: Yayasan Pendidikan Al-Qur'an Raudhatul Mujawwidin.

Riduan. (2007). Belajar mudah penelitian untuk guru, karyawan dan peneliti pemula, Bandung: Alfabeta.

Riyanto Yatim. 2001. Metodelogi Penelitian Pendidikan. Surabaya : SIC

Salim Zarkasyi, Dachlan. 1990. Qiroati Metode Praktis Belajar Membaca Al-Qur'an jilid 1-VI. Semarang: Yayasan Pendidikan Al-Qur'an Raudhatul Mujawwidin.

Salim Zarkasyi, Dachlan. 1996. Empat Langkah Pendidikan TK/TPQ Metode Qiroati. Semarang: Yayasan Pendidikan Al-Qur'an Raudhatul Mujawwidin.

Salim Zarkasyi, Dachlan. Memahami Qiroati. Semarang: Yayasan Pendidikan Al-Qur'an Raudhatul Mujawwidin.

Sugiyono. 2011. Metode Penelitian Kuantitatif Kualitatif dan R \& D cet ke 8. Bandung: Alfa Beta.

Sunhaji. 2009. Strategi Pembelajaran Konsep Dasar, Metode, dan Aplikasi dalam Proses Belajar Mengajar. Yogyakarta: Grafindo Litera Media.

Susanto, Ahmad. 2013. Teori Belajar dan Pembelajaran di Sekolah Dasar. Jakarta: Prenadamedia Group. 